\title{
Agritourism and architecture of typical churches in Cossack settlements in the Middle Volga
}

\author{
Elena Ponomarenko ${ }^{1, *}$ and Ludmila Ivanova ${ }^{2}$ \\ ${ }^{1}$ Scientific Research Institute of Theory and History of Architecture and Urban Development 7-ya \\ Parkovaya str. 21a, 105264, Moscow, Russia \\ ${ }^{2}$ Academy of Architecture and Civil Engineering, Samara State Technical University, \\ Molodogvardeyskaya str. 194, 443001, Samara, Russia
}

\begin{abstract}
The article analyzes the tourist potential of the cult architectural heritage of the Middle Volga region for agrotourism. The urgency of the problem under investigation is determined by the ever-increasing interest in architectural traditions of ethnical and sub-ethnical communities in various Russia's regions, including the Cossacks. The methodology of the study is based on a comprehensive architectural historical analysis of the layouts and design of churches in Cossack settlements in the region. The author analyzes a wide range of issues related to the architectural layout, composition and character of churches in Cossack settlements in the 16th-20th centuries. The paper reveals an interesting stratum of regional heritage. It contains a description and analysis of little-known architectural monuments based on the author's field surveys of the remaining settlements. The work includes examination of comprehensive archival data from local and central archives, as well as rich graphical material. The findings in this paper can provide a framework to further research in the area of architecture culture of the Cossacks in the Mid Volga regions.
\end{abstract}

\section{Introduction}

Recently, some tourists prefer to spend their holidays in the countryside, where you can spend a few weeks living in village houses, being acquainted with the rural way of life, with local culture and local customs. Aagritourism includes ethno tourism, including familiarity with the way of life of the Cossacks. In the life of the Cossack settlement, a large place has always occupied the church. The urgency of the subject matter of the paper is determined by the fact that the role of Russia's regions has been on the increase; consequently, key findings and conclusion of studies under way may be critical for the work of preserving and reviving the historical environment of these settlements. The formation of historical consciousness is currently of great importance; interest in the role of regional traditional architectural and urban planning culture in modern life has been significantly increasing. The architectural and urban planning culture of the Russian Cossacks is a substantial part of the architecture and urban planning of the Russian State provinces. Urban planning and architecture is the least studied areas of artistic and historical culture of the Cossacks from the Volga region and entire Russia.

In order to reveal national features of architectural and town-planning culture of Russian Cossacks, without any doubt, means to first study local and regional versions of this culture.

\footnotetext{
* Corresponding author: evpon@mail.ru
} 
My methodology is based on comprehensive historical architectural analysis of the most typical churches in Cossack settlements. The cornerstone method of the study is historical architectural analysis and wide archival research leading to generalization of data from documents, field data, ethnographic and historical materials. Relying on the "historical, memorial, cultural/ideological and aesthetic" aspects of the value of this architectural heritage, revealed by A.S. Shchenkov [1], the author of this paper proposes a paradigm facilitating analysis of such architectural structures.

No full-scale study of the architectural culture of the Cossacks has been done so far. The beginning of research on Volga Cossacks culture was launched in late XIX - early XX c. In early XX c. a series of works appeared where, along with such issues as the history, organization and the then current state of the Cossack Army, some attention was paid to architecture.

The best-investigated portion of the Cossack culture was that of the Caucasus and Kuban river communities. There is a fundamental work, in two volumes, titled "The history of the Cossack Army", F.A. Shcherbina Typography, 1910 [2], where the development of these military units was studied in a great detail. However, even in this book only a paragraph was given to the issue of “a Cossack's household". In this respect, very typical is a monograph by A.I. Riegelmann “A History of or Narration about Don River Cossacks" [3] that came out in 1846. It is a key subject is how the Don River Cossack Army was initially formed and subsequently developed. The Volga River Cossacks fell out of its scope and consideration.

Russian historians occasionally touched upon the subject in conjunction with other ethnographic issues. This was, first and foremost, V.N. Vitevsky [4]. Exemplary was his work "Russian Orthodox Church Schism in the Urals Cossack Army and how it was perceived and reacted to by church, civil and military authorities in XVIII and XIX c.». In much more detail the issue was tackled by E.P. Savelyeva in her three-volume book "The Old history of Cossacks", "The Medium History of Cossacks" and "The Don River Democratic Republic of Cossacks" [5]. Widely known are monographs by P.N. Bibik ("The Terek River Cossacks. Their history and revival" [6]), Yu.A. Trofimov ("The Terek River Cossacks: history, traditions, customs" [7]), V.O. Kluchevsky ("A history of social classes in Russia" [8]), L.N. Gumilev ("Ancient Russia and the Great Steppe" [9]), V.A. Potto ("Two centuries of the Terek River Cossacks" [10]), etc. However, architectural history of Cossacks is not considered there at any length, except for sporadic day-to-day life sketches.

Somewhat closer to the subject declared herein are works by F.M. Starikov ("Historical and statistical essays on the Orenburg Cossack Army" [11]) and A.I. Krivoshchekov ("At the Orenburg defense line: essays on Cossaks' past history" [12]). On the other hand, these authors touch upon the issues linked to architectural traditions of Cossacks only indirectly since in the main focus of their consideration are folk art, rituals and customs.

Foreign scientists considered the history of the Cossacks. The French historian Charles Louis Lesur wrote in 1814 on the orders of Emperor Napoleon "The History of the Cossacks." In this book, he examines some examples of Cossack customs. However, the Cossacks for Lesyur ethnographic concept, he considers the Cossacks isolated people. Despite the commonality of language and religion, it divides Russians and Cossacks, compares the life and manners of the Black Sea Cossacks with the customs of the Huns and Pechenegs [13].

In the book, L. J. Carr examines the stay of the Cossacks in France during the war of 1812. In the latest chapter, "Analysis of the various Russian peoples who today serve as Cossacks" the author distinguishes between Don and Ukrainian Cossacks, but he analyzes only their clothes, weapons and methods of warfare [14]. 


\section{Methodological Framework}

The cornerstone method of the study is historical architectural analysis and wide archival research leading to generalization of data from documents, field data, ethnographic and historical materials.

The systems approach implies relying on the methods of genetic history, architectural and town-development analyses (typological and stylistic). It is particularly important that such an approach allow considering many aspects of sub-ethnic, national and confessional peculiarities of architecture.

We have searched through and analyzed documents from central and regional archives, museums and cartography divisions of libraries. Among other materials, we have studied extensively on cartography sources dating back to XVIII and XIX cc.: provincial maps, maps of defensive border lines and fortresses; county/district maps of fortified settlements and Cossack villages. We also did a comprehensive analysis of building plans, façade layouts and photos of most typical structures, including those inexistent by now. Multiple published sources - books by foreign and Russian geographers, travelers' memoires and accounts from medieval ages, XVIII and XIX cc., subject collections and periodicals - have been considered and analyzed.

\section{Results}

The first Cossacks who appeared on the territory of the Middle Volga and adjacent lands in the middle of the $15^{\text {th }}$ century were not soldiers of the regular army but 'free' people involved in robbery. Those freemen formed an independent Cossack community, the largest center of which was located near the Zhiguli Mountains.

At that time, merchant convoys were moving through the Middle Volga to the Don River or the Yaik River (former name of the Ural) and sailing along the Volga. The Middle Volga Cossack freemen were most active at the end of the $16^{\text {th }}$ century. Central (Moscow) authorities tried to get these Cossacks involved into transportation along the Volga, but all these attempts were unsuccessful (Figure 1).

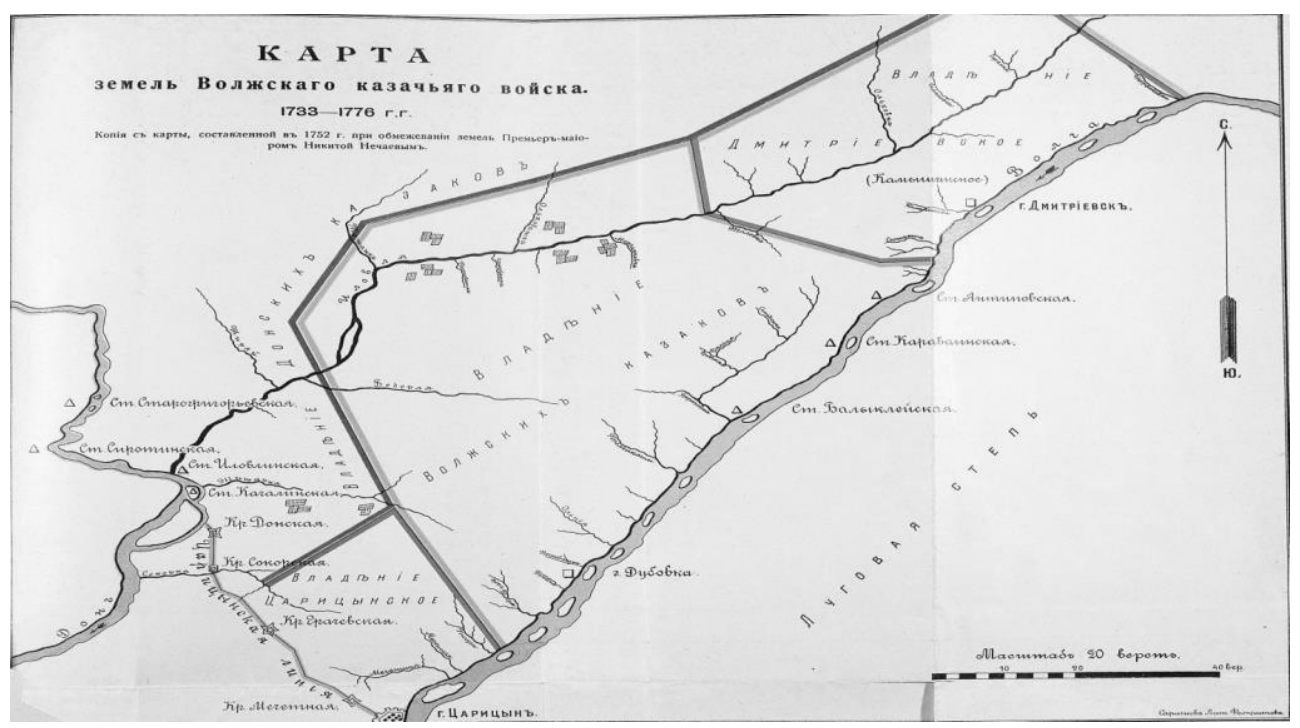

Fig. 1. Map of lands accommodating the Volga Cossack Host in 1733-1776 
In the middle of the $16^{\text {th }}$ century, a part of the Cossacks remained at their original location. Some of them returned to the Don; others migrated east to the river Yaik. A significant number of the Cossacks (more than 7000) stayed near the headquarters of the chieftain (Russian ataman) Yermak (the modern village of Yermakovo in the Zhiguli Mountains in Samara Oblast) [15].

Thus, it was the beginning of the Cossack freemen community on the territory of Orenburg. In the $18^{\text {th }}$ century, P.I. Rychkov spent much time travelling and studying the history of the region. 'In those old days $<\ldots>$ there was a man hailed from the Don Cossacks, of the name Vasily Gugnya; this man, having taken around thirty people out of the local Cossacks as partners <...> went away from the Don on business or, more to say, for theft' [16]. That is how P.I. Rychkov describes the emergence of free Yaik Cossacks. A group of Cossacks-robbers took cover in the reeds on the Caspian Sea and headed for the Yaik River and set up a camp there.

The settlements of free Cossacks were mainly of two types: gorodok - town for permanent residence and zimovka (zimovye, zimovishche) — winter camp, settlement that was used only in winter. As noted by M.N. Kharuzin, 'zimovishcha were just winter shelters abandoned in early spring for militant raids' [17].

The Cossack town's gorodki of the $16^{\text {th }}-17^{\text {th }}$ centuries were well-protected settlements with randomly arranged huts within wooden and earthen fortifications. They evidently served military purposes. As a rule, in the center of a town, there was a square for the council gatherings (Kazachiy krug) and a church.

Another important type of military settlements of the period under review was Russian fortresses, where Cossacks of different nationalities eventually started to serve. The policy of building fortified lines at the borders appeared in Russia in the $15^{\text {th }}$ century, when the first zasechnaya liniya - line of defense (abatis) — was constructed and included the settlements of Tula, Kozelsk, and others. However the last quarter of the $16^{\text {th }}$ century, it evolved into a long Belgorod line of defense and went far to the south.

In 1551, a fortress was built in the mouth of the Sviyaga River; it was named after the river. The fortress was necessary to defend against the attacks of nomads and to control trade. The important task of the military post was to combat the Volga Cossack freemen. Simultaneously with the city in 1551 was built a wooden Trinity Church, which has survived to this day (Figure 2).

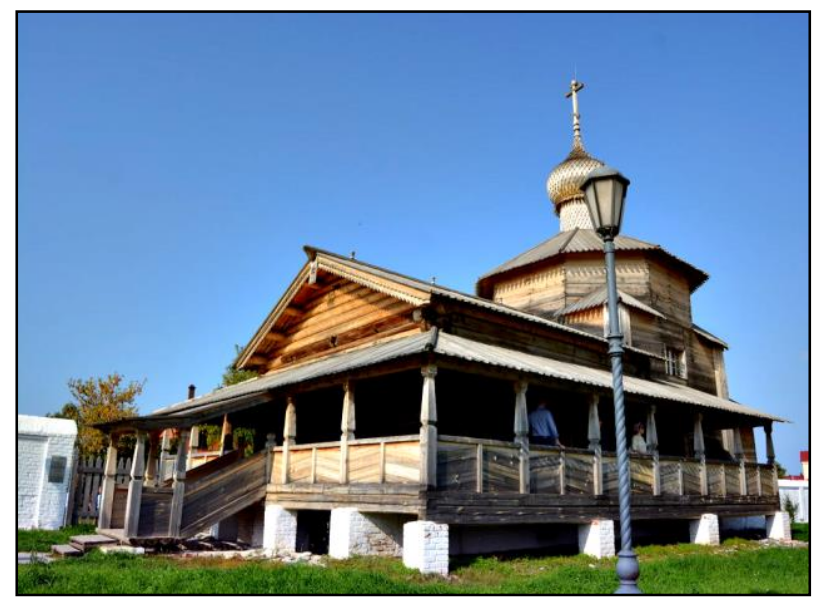

Fig. 2. Trinity Church in Sviyazhsk

This church is large, because next to it held meetings of cossacks of the whole village (Kazachiy krug). From the point of view of its aesthetics, this is a very typical religious 
building made of wood in Russia's deep hinterland. Along the main axis, there were sequentially arranged: narthex superimposed by a bell-tower, refectory, the elevated main space of the church (dais), and the altar. The refectory and the main room of the church made up a single structure.

The project design and erection of churches, specifically in local villages, was conducted not by professional architects having a university degree, but by crews of masons invited to form the Dalmatov Monastery or from central Russia's regions [18].

The second quarter of the 18th century was the time when large-scale shaping of architectural and urban planning legacy of the Russian state began; at the same time regular re-planning of largest urban settlements and re-building (in stone) of their respective central architectural ensembles started only as early as the first half of the 19th century. In the centre of the town it was permitted to erect only masonry civic houses, whereas public establishments had to be built according to approved facade designs [19].

Early 19th century was marked by a rising concern of governmental officials for the development of ecclesiastical architecture in the frontier regions of the country. In Synod edicts of 1826 and 1828, it was prescribed that generally, churches and cathedrals in the country should be built according to ground plans, designs and projects in compliance with architectural rules and canons (Synod decrees...). Ecclesiastical architecture in this period came to be a symbol both expressing and asserting Russian rule and domination on its territories adjacent to the borders. A regular town/building plan and an exemplary project thereof were the key transmitters of this policy. With this purpose in mind, projects and drawings were made in the metropolis describing model church designs. One of such projects - although later reworked in situ - was the Church of the Mantle of our Lady in the village Kardailovo, Orenburg province. The church was built in 1835. Situating the building in the center of the village and accentuating its north-facing elevation in visual perspective if viewed from a distance, was what allowed to vividly mark out the most aesthetically interesting part of the building - the rotunda. In the initial version of the project, the structure comprised sequentially arranged rectangular refectory and rotunda. A four-column Tuscan portico adorned the western façade. In 1849, a bell-tower was added to the church, with a short passage to the refectory, of the same width. A new Tuscan porch was built with columns echoing pilasters, and a two-column portico with an entrance to the rotunda at the southern facade (Figure 3). Evolution of the regional church design was interrupted by the arrival of the Soviet rule. New churches were not built at that time. Demolition and barbaric replanning/conversion of ecclesiastical buildings contributed to the distortion of the historic architectural environment in towns and cities. Professional architects had been gradually but steadily losing their knowledge of general norms and rules of church construction along with the traditions of regional ecclesiastical architecture

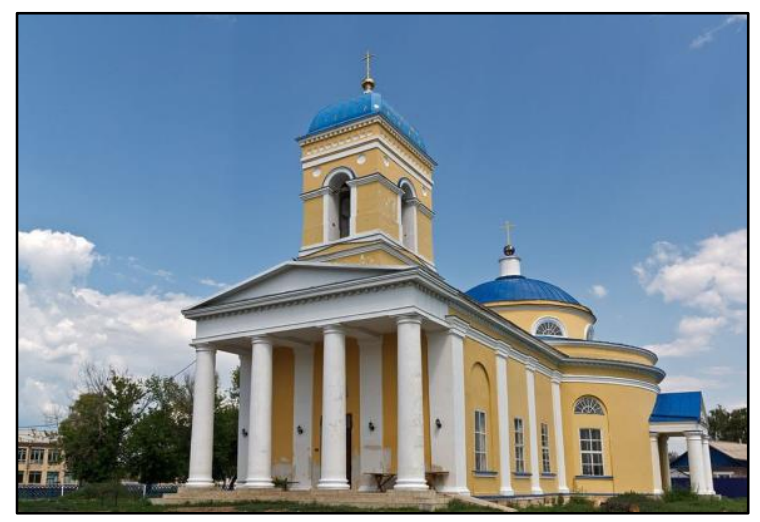

Fig. 3. Church in Kardailovo 
Beginning in the last decade of the 20th century, Russian society came to a revival of their interest in church architecture. This is the reason why the architectural form of churches is today in no small degree determined by building-owner desires and requirements. Today, stylization is a method most widely used in the region for the purposes of drawing on the historical architectural heritage in new development projects. In Cossack settlements the retrospective architectural schools and tendencies of the late 19th - early 20th century are being imitated most often.

Of greatest interest are the projects where church construction is not initiated from above, with prescribed parameters of a pompous ceremonial style, but the building of chapels or small churches prompted, financed and sometimes carried out by local residents of the middle class. One of the vivid examples of this sort of initiatives is the erection, in 2003, of Peter and Paul Chapel. It is situated in the Orenburg region near Pogromnoye village. Its construction was initiated by Vladimir Denisov whose own architectural expertise and experience were limited to a diploma he got at a civil engineering college. The Peter and Paul chapel boast harmonious proportions of a one-dome main building and a powerful, squarelayout bell-tower. Despite the fact that in the design of the chapel we can see no distinct regional models and prototypes, the appearance of such initiatives and their harmonic composition and forms reminiscent of the old Russian church architecture is a very interesting tendency exhibiting people's aspiration to revive national ecclesiastic building traditions in Cossack settlements (Fig. 12). The striving of people of very different prosperity to build new churches is what invests the whole story with a lot of optimism because in the situation when government policies and laws on cultural heritage protection and conservation are inefficient, the building of churches and attempts to find a new regional model for ecclesiastical architecture is what contributes significantly to the elevation of moral standards and revival of cultural authenticity of the region.

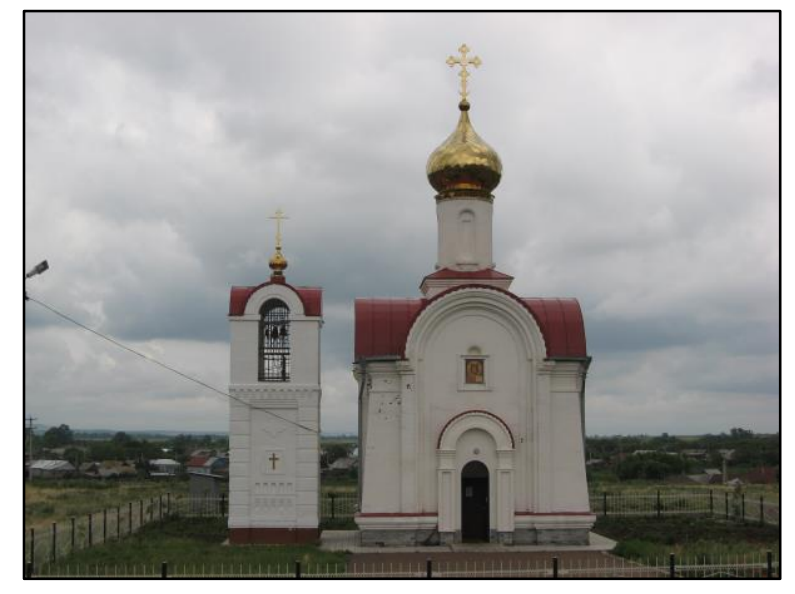

Fig. 4. Peter and Paul Chapel

\section{Discussion}

Altogether, up till now, no comprehensive studies on architecture of the Cossacks in the Mid Volga have been put on the table. In a fragmentary fashion, this issue has been tackled in the works written by architects such as G.V. Yesaulov, [20], N.N. Velikaya [21], A.G.Lazareva [22], S.D.Sulimenko [15], S.O.Terekhina [23], and others.

Currently, foreign scientists are doing research on the history of the Cossacks. A typical example is "Qazaqlïq, Or Ambitious Brigandage, and the Formation of the Qazaqs: State and 
Identity in Post-Mongol Central Eurasia" by Ju Li. In this work there is a section "History of Crimean, Kasim and Volga Tatars." However, the author attributes the Cossacks to the Turkic-Mongolian peoples of Central Asia and confuses with Kipchak [24].

In recent decades, we have witnessed a revival of Cossacks. On the other hand, the status quo of this movement cannot be regarded as definitely settled. In many a document, for instance in "The Concept of public policy on the Cossacks in the Volgograd Region" (2011), the Cossacks are termed 'an ethnic group'. In other documents they are called 'cultural-ethnic community, 'social-ethnic community', 'class'.

In this connection, new studies have been showing up. Individual contributions to this issue were made by A.V. Venkov ("Veshenka Village Uprising" [25], A.A. Gordeev ("A history of Cossacks" [26], S.A. Kozlov ("The Caucasus in the history of the Cossacks" [27]), O.V. Matveev ("A Historical account of the Kuban River Cossacks' worldview: social aspects of warrior mentality" [28], etc. All these works, to a large degree, deal with the history of Cossacks, while their architectural and town development culture and traditions are considered there only in fragments. Concurrently with the revival of the Cossack movement and due to it, an abundance of amateurish and politicized publications on the subject are coming out. All the works considered here focus on Cossack settlements in various regions of Russia except for the Mid Volga. The villages are analyzed from the perspective of their development history or the state and condition of individual monuments in this or that historical period. The problem of revealing the patterns and tendencies of how the architecture of churches in Cossack settlements and what its peculiarities are is, alas, not becoming the object of contemplation or analysis.

\section{Conclusion}

Thus, by the early $19^{\text {th }}$ century, in the Middle Volga and adjacent territories, there had been an established settlement system, an important part of which was the fortified lines of the Cossack fortresses. There were redoubts — the smaller fortifications — between the fortresses of all lines. The most significant element in the fortress-settlement composition was the churches. Surpassing the residential areas in size and expressiveness, churches successfully fitted into the surrounding landscapes and made a strong artistic impression on their contemporaries.

\section{Recommendation}

Currently, we are witnessing a revival of cultural traditions of ethnic and sub-ethnic populations in various Russia's regions. This process manifests itself in restoration and reconstruction of individual settlements. At the same time, we observe a steady rise in the public interest towards architecture as component of cultural and spiritual heritage. The practical value of this study is that is allows: carrying out comprehensive and systematic restoration and reconstruction of former Cossack settlements relying on newly revealed knowledge; better fitting new buildings in the historical and architectural environment, not spoiling at this the individuality of a town of a city.

\section{References}

1. A. Shchenkov, Restoration and Architectural Archeology. New Materials and Investigations 2, 29-37 (1995)

2. F.A. Shcherbina, The History of the Kuban Cossack Host: The History of the Region (Kuban Regional Board Printing House, Ekaterinodar, 1910) 
3. A.I. Rigelman, The History or Story of the Don Cossacks (University Printing House, Moscow, 1846)

4. V.N. Vitevskiy, The Split in the Ural Army and the Attitude of Spiritual and CivilMilitary Authorities in the 18th and 19th Centuries (Imperial University Printing House, Kazan, 1878)

5. E.P. Savelyev, The Cossacks. History (SPAS, Novocherkassk, 1915)

6. P.N. Bibik, Terek Cossacks. Pages of History and Revival (YURKIT, Stavropol, 2001)

7. Y.A.Trofimova, Terek Cossacks: History, Traditions, Customs (Kint, Pyatigorsk, 1994)

8. V.O. Klyuchevsky, The History of Russian Classes (Kniga po Trebovaniyu, Moscow, 2012)

9. L.N. Gumilyov, Ancient Russia and the Great Steppe (AST, 2003)

10. V.A. Potto, Two Centuries of the Terek Cossacks. 1577-1801 (Terek Regional Board Electric Printing House, Vladikavkaz, 1912)

11. F.M. Starikov, Historical and Statistical Sketch on the Orenburg Cossack Host (Breslin's Printing House, Orenburg, 1891)

12. A.I. Krivoshchekov, Vestnik Orenburgskogo uchebnogo okruga 1, 99-123 (2010)

13. Ch.-L. Lesur, Histoire des cosaques (Paris, 1814)

14. L.J. Karr, Des cosaques ou détails historiques sur les moeurs, coutumes, vêtemens, armes; et sur la manière dont ce peuple fait la guerre; recueillis de l'allemand (Paris, 1814)

15. S.D. Sulimenko, Towers of the North Caucasus (Spatial Symbolization in the HouseBuilding Creativity of the Highlanders (Proekt-Press, Vladikavkaz, 1997)

16. P.I. Rychkov, History of Orenburg (1730-1750) (Orenburg Regional Statistical Committee Publishing House, Orenburg,1896)

17. M.N. Kharuzin, Information about Cossack Communities (M.P. Shchepkin's Printing House, Moscow, 1885)

18. L. Sukhodolskiy, The Orenburg Eparchial News 14, 53-54 (1854)

19. N. Stremskiy, Martyrs, confessors and churches of the Orenburg Diocese. 20th (Russia, Saraktash, 1999)

20. G.V. Yesaulov, World Arkhitekture 4, 128-145 (1995)

21. N.N. Velikaya, The Cossacks of the Eastern Ciscaucasia in 18th-19th Centuries (Rostov-on-Don, 2001)

22. A.G. Lazarev, Architecture and Urban Planning in the South of Russia. History. Traditions. Current Trends (Rostov State University of Civil Engineering, Rostov-onDon, 2001)

23. S.O. Terekhin, National and Regional Peculiarities of the Saratov Volga Region Architecture (Saratov State Technical University, Saratov, 2002)

24. J.Y. Lee, Qazaqlï, Or Ambitious Brigandage, and the Formation of the Qazaqs: State and Identity in Post-Mongol Central Eurasia (Brill, Nederland, Leiden, 2017)

25. A.V. Venkov, Vyoshenskoye Uprising (Veche, Moscow 2016)

26. A.A. Gordeev, The History of the Cossacks (Veche, Moscow,2006)

27. S.A. Kozlov, Caucasus in the Fortunes of the Cossacks (16th-18th Centuries) (Kolna, St. Petersburg, 1996)

28. O.V. Matveev, Cossacks of Russia: Past and Present. A Collection of Articles 1, 396411 (2006) 